\title{
Neoliberalism, Law, and Its Discontents: Three Recent Interventions
}

\author{
Ravi Malhotra
}

Honor Brabazon, ed, Neoliberal Legality: Understanding the role of law in the neoliberal project (New York: Routledge, 2017). 214 pp. Paperback \$49.95

Katharina Pistor. The Code of Capital: How the Law Creates Wealth and Inequality (Princeton: Princeton University Press, 2019). 297 pp. Hardcover \$29.95

Astra Taylor, Democracy May Not Exist, but We'll Miss It When It's Gone (New York: Metropolitan Books-Macmillan, 2019). Hardcover $\$ 27.00$

(Editor's note) This review essay is part of Left History's commitment to progressive scholarship and publication. Our recent transition to an online-only, open-access journal creates a range of possibilities, whether it be a new audience or forms of collaboration. With that in mind, Left History partnered with Legal Form, an online platform for Marxist legal analysis, to cross-publish Ravi Malhotra's evaluation of three works focused on the contours of neoliberalism, laws, inequality, and democracy. We hope that our journal will continue to be a site for collaboration and conversation.

As the proliferation of market forces as the central organizing principle of modern society continues, the lives of countless workers have been disrupted. Factories have relocated to cheaper locales and governments increasingly impose austerity budgets that limit spending on human needs such as health, education, and the environment. These transformations have generally come to be known as neoliberalism. In these dire circumstances, historians and legalscholars are interrogating what precisely is meant by neoliberalism and its relationship to law and democracy itself. Law offers both the possibility to harness the regulatory power of the state to challenge neoliberal orthodoxies as well as the peril of being implicated in strengthening market principles and private ordering. Law is never simply about deregulation but involves the reconstitution and redeployment of the state. The innovative design of legal institutions offers the promise of building a more egalitarian, just society through wealth redistribution yet is situated in the context of law as a tool that serves to reinforce hierarchy and bureaucratic meritocracy.

According legal personhood to corporations, a trend commencing in the United States in the late nineteenth century, has had profound implications around 
the world for how decision making is structured, including taxation avoidance that enables some of the world's wealthiest corporations to pay minimal tax. ${ }^{1}$ The law of bankruptcy has enabled corporations to avoid their obligations to many creditors, leaving a wake of disaster and chaos behind while derivative traders successfully lobbied for exemption from traditional priority of creditor principles. ${ }^{2}$ Intellectual property law, encompassing patents and trade secrets, has allowed corporations to make massive profits from expensive new drugs such as Eli Lilly's Strattera and Zyprexa, designed to treat people diagnosed with schizophrenia and depression. ${ }^{3}$ Liberal notions of contract law structure how states such as Britain impose workfare contracts (which require individuals to achieve certain objectives in order to maintain their social assistance benefits). ${ }^{4}$ And a growing number of municipalities in the United States have reformulated local legal codes in order to deny corporations the status of personhood so as to prohibit fracking. ${ }^{5}$ All of this has important implications about how one thinks about democracy and the governance of society by the will of the people. Ultimately, law through regulatory codes and standards on a wide range of topics from product liability to environmental regulation shapes the content of democracy and how we envision it, even as its repressive functions frequently serve to undermine movements for social justice and equality.

Three recent books that grapple in their own way with the themes of neoliberalism, law, and democracy are the anthology Neoliberal Legality, edited by Honor Brabazon, a sociologist at St. Jerome's University, The Code of Capital, authored by Katharina Pistor, the Edwin B. Parker Professor of Comparative Law at Columbia Law School, and Democracy May Not Exist, but We'll Miss It When It's Gone, authored by film maker and public intellectual Astra Taylor. Each of these books addresses the themes of neoliberalism, law, and democracy from different vantage-points and disciplinary traditions, with varying degrees of success. And each leaves the reader with more questions about how we can build a more robust conception of democracy, in a world facing environmental degradation and the ominous centrality of the market as the governing paradigm.

\section{Neoliberal Legality}

Neoliberal Legality is an anthology based on conference papers that Brabazon organized at the University of Oxford in 2013. Featuring scholars from Canada, Britain, and elsewhere, the essays in this collection interrogate what exactly is meant by neoliberalism as a juridical project. It is also the most academic of the books under review here, a strength and occasionally a weakness. Given that this is an anthology, my treatment is necessarily selective. Chapters encompass topics such as law and development, social policy and law, labour law, Indigenous rights, and others, always through the analytic prism of neoliberalism. In her introductory essay, Brabazon rightly suggests that the literature on neoliberalism has primarily focused on its political and economic dimensions. ${ }^{6}$ Yet few scholars have considered the relationship between law and neoliberalism. As Brabazon sug- 
gests, the two concepts might be regarded as co-constitutive, as law shapes the regulatory priorities and constraints of neoliberalism while neoliberalism itself influences contemporary interpretations of legal doctrine. ${ }^{7}$ This book accordingly aims to analyze what exactly is distinct about neoliberal law as an ontological category and legal form, the implications of this claim for public policy, and the potential for social transformation.

Brabazon suggests that neoliberalism is the dominant ideology of our time since the 1980s, but acknowledges that there is imprecision and debate as to its exact meaning. ${ }^{8}$ One contributor to the volume, Andrés Palacios Lleras, usefully provides a concise definition of neoliberalism: "a doctrine that views free markets as essential for preserving freedom, and that views such markets as the result of active political choices aiming to protect and preserve freedom."' For her part, Brabazon identifies three overlapping strands. First, it can be regarded as a normative political theory developed jointly by ordoliberals associated with the Freiburg School in Europe and the Chicago School in the United States. Viewed in this way, it is not simply a set of policy proposals but an articulation of a philosophical perspective actively engaged in responding to the rise of the Soviet Union and its satellite states, Nazi Germany, and the social democratic welfare state. It is an intellectual project formulated by thinkers such as Hayek with enthusiastic followers that seek to disseminate the ideas at conferences, through policy networks and in the classroom. ${ }^{10}$ Second, building on work by scholars such as David Harvey and David McNally, she sees it as a class-based political project designed by elites to restore the optimal conditions for capital accumulation. ${ }^{11}$ Finally, influenced by Michel Foucault and others such as Pierre Dardot and Christian Laval, she regards neoliberalism as a totalizing rationality that seeks to create neoliberal subjects. ${ }^{12}$ The commodification of post-secondary education is a classic example, resulting in many students who regard their relationship with universities as a purely market transaction and feel wronged when they are not awarded the grade they feel that they effectively purchased. ${ }^{13}$ Brabazon persuasively demonstrates that all three strands need to be acknowledged to have a comprehensive understanding of neoliberalism. I feel a strength of the volume is emphasizing how the creation of neoliberal subjects who feel a stake in preserving its values is essential to promoting neoliberalism as an ideology.

One important theme that is highlighted in this anthology is the role of the state. Contrary to perceptions that neoliberal ideology entails a downsizing of the role of the state, the essays make it clear that a strong state is essential for establishing the conditions for capitalist competition and accumulation under neoliberalism. ${ }^{14}$ This is not a novel insight; nevertheless it bears repeating and the evidence for it is meticulously marshalled in the volume. For example, the chapter by Andrés Palacios Lleras demonstrates how there has been an expansion in the authority of autonomous regulatory agencies in areas such as securities regulation, environmental law, and competition law. By limiting the ability of elected officials to implement 
policies, the state facilitates capital accumulation by leaving critical decisions to agencies where powerful corporations can more easily influence outcomes that are depicted as scientific, rational, and neutral. ${ }^{15}$ This marks a shift in the role of the state but nonetheless requires competence and capacity on its part to build effective regulatory institutions.

Similarly, a chapter by Nicolás M. Perrone illustrates a shift in the role of the state in the context of foreign investment relations. Perrone documents how bilateral investment treaties require disputes between foreign investors and host states to be heard before an international arbitration tribunal, bypassing domestic courts which are more likely to be unfavourable to foreign investors. These tribunals have enshrined contract doctrines such as the initial intent of the parties to justify a focus on the legitimate expectations of the parties. ${ }^{16}$ This marks a shift from earlier legal doctrines that placed greater emphasis on the sovereignty of the state, as witnessed by the 1952 ruling of the International Court of Justice (ICJ) in the Anglo Iranian Oil Company case, regarding the nationalization of British investments by a nationalist government in Iran. ${ }^{17}$ In that case, the Court ruled that the ICJ had no jurisdiction because Iran had conceded jurisdiction to the Court only with respect to treaties signed after $1932 .{ }^{18}$ This ended with the subsequent overthrow of the Mossadegh government by British and American intelligence the following year. ${ }^{19}$ While it is certainly true that the role of the state has changed, I would note that again a state willing and able to conclude a bilateral investment treaty is a pre-condition of a neoliberal investment regime.

Brabazon's anthology also underscores the point that in many areas of the law, more intrusive legal regulation is a core manifestation of neoliberal legalism. This is evident in the regulation of labour relations, as documented by excellent chapters by Robert Knox, about the transformation of British Labour law, one of the highlights of the volume, and by Ntina Tzouvala, on the imposition of legal restrictions of the right to strike in the Greek context. ${ }^{20}$ Influenced by the work of Dardot and Laval to stress the importance of how neoliberalism creates neoliberal subjects, Knox painstakingly shows how neoliberal subjectification has transformed British trade unions in the last thirty years. Whereas once even mainstream bureaucratic unions had posed the potential of an alternative vision of society in which working class people had real power and at least tried to articulate the interests of the entire working class, under Thatcherism trade unions acquired a much narrower outlook focused on day-to-day policies as legislative amendments to the various British labour law statutes led to precipitous declines in the union density rate. ${ }^{21}$ Knox also importantly identifies a shift from regulation of the labour relationship through collective bargaining between unions and management, which historically was minimally regulated by the state, to a greater role for regulation of the employment relationship through minimum wage legislation and health and safety and antidiscrimination law. ${ }^{22}$ I question whether this phenomenon, which has occurred in many other countries including Canada, is an entirely negative development. Unions 
in their Keynesian heyday failed to sufficiently engage with racialized people, women, disabled people, and others. Nonetheless, Knox's point is a powerful one, elegantly argued, and warrants further investigation.

The volume concludes with an engaging chapter by Vanja Hamzic on alegality, which he defines as the "capacity to be neither legal nor illegal, an ability to exist and act in the interstices, or perhaps beyond or outside, the dominant (capitalist) modes of legal production." ${ }^{.23}$ Hamzic suggests that notwithstanding the dominance of neoliberal discourse, a legal discourse contains an opportunity to further anti-capitalist struggle. Building on his ethnographic work conducted in the slums of Lahore, Pakistan, he identifies how communities engaged in sex work, ritual dancing, or begging thrive outside or on the discursive and spatial fringes of law. In this environment, an alternative kinship household known as khwajasara might serve as a family home, brothel, dance studio, beauty salon, and school. State law is largely absent in this context. Hamzic identifies how other forms of resistance take on a purely discursive cast, citing James C. Scott's ideas of a "hidden transcript" where subaltern peoples resist the discourse of the dominant. In the right circumstances, such a discourse might fuel a popular rebellion with its own counter-hegemonic discourse. ${ }^{24}$ While at times one wonders whether this is simply a repackaged statement of legal pluralism, Hamzic's sophisticated take on the potential of transcending late capitalism is captivating, a fitting close to Brabazon's fine volume.

\section{The Code of Capital}

While Brabazon may be faulted for occasionally being inaccessible to a non-academic audience, Pistor's The Code of Capital goes out of its way to try to make its arguments comprehensible to a broad audience. Written in the aftermath of the 2008 financial crisis, Pistor's main argument is that legal coding, as exemplified by contract, property rights, trust law, bankruptcy law, and other "modules," creates wealth. She identifies four characteristics of legal modules which she asserts bestows critical attributes on assets, thereby benefitting their owners: priority, durability, universality, and convertibility. Priority refers to how competing claims to the same assets are ranked. In bankruptcy law, certain classes of creditors are typically given priority over others, with dramatic implications for those with less priority. Durability establishes priority claims in time. One would always prefer an asset which is durable in the long term. Universality establishes priority claims across space. An asset which cannot be easily transferred to another jurisdiction without penalty is of limited utility. Finally, convertibility ensures that an asset can be converted into state money on demand. ${ }^{25}$

Pistor argues that capital is made from two variables: an asset and the associated legal code. She claims that legal coding is the key behind wealth creation in capital. ${ }^{26}$ Individual chapters are devoted to illustrating how law codes land, corporations, debt, and intellectual property. For instance, Pistor traces the history of property law in England and colonial America, rapidly condensing centuries of legal 
history at a dizzying pace to show how land law facilitated the concentration of land ownership in the bourgeois classes. She shows how American courts typically struck down debt moratoria enacted by states that sought to alleviate the burden of working class farmers at the mercy of commodities markets on the grounds that such reform initiatives violated the Contract Clause. ${ }^{27}$ Yet almost completely absent from her analysis of coding is any deep engagement on class relations and the role of the working class in creating the wealth in society.

A chapter devoted to corporate law provides an analysis of the demise of Lehman Brothers. This collapse was a near-fatal heart attack at the core of the global financial system. Pistor shows how Lehman Brothers had hundreds of registered subsidiaries in dozens of countries around the world. This allowed for the legal partitioning of assets because corporate law facilitated the creation of corporations with minimal regulatory oversight. When the parent company could no longer guarantee the debt of its subsidiaries, the entire legal edifice collapsed like a house of cards. ${ }^{28}$ Pistor also usefully identifies other aspects of corporate law that allow corporations to prosper, including tax sheltering by companies such as Apple which created subsidiaries in Ireland purely to avoid taxes. ${ }^{29}$ Again though the focus is entirely on what I think are secondary phenomena in the financial sector without a solid appreciation of the importance of class issues in the real economy.

Another chapter traces the history of debt. Again, Pistor frames the issue as a matter of legal coding. She tells the story of NC2, a mortgage originator trust established in 2006. The subprime mortgage tale is widely known, but Pistor adds colour and detail, explaining how assets in NC2's mortgage pool were tranched and each asset was ranked. Eventually, banks eager for higher returns on their investment were left holding toxic debts. ${ }^{30}$ Similarly, she recounts the story of Kleros Real Estate, a company designed to facilitate investment through a complex series of transactions in the least desirable tranches of the mortgage securitization business. ${ }^{31}$ Pistor weaves in a history of bills of exchange, noting how they were effective in bypassing anti-usury laws in place and fostered the expansion of trade. ${ }^{32}$ While this history is well written, it appears divorced from an understanding of the global economy as a whole.

A chapter devoted to intellectual property examines the manner in which the British and Austro-Hungarian empires used patent policy to cement their industrial policies. Pistor demonstrates how patent policies in the Austro-Hungarian Empire led to the adoption of the 1883 Paris Convention for the Protection of Industrial Property. Eventually countries such as the United States began to use trade sanctions to penalize states that they perceived as infringing on their intellectual property, despite having earlier benefitted from protectionist policies. ${ }^{33}$ Pistor is right to emphasize how corporate leaders played a key role in directing the policies of American intellectual property policy. She notes how the Intellectual Property Committee, founded in 1986, consisted of leaders from major corporations such as DuPont, IBM, and Johnson \& Johnson, among many others. ${ }^{34}$ Similarly, TRIPS, the 
international intellectual property agreement, reflected the interests of Western industrialized countries and their major corporations.

While Pistor's approach allows her to thoughtfully write about how various debt instruments played a role in worsening the 2008 crisis, I cannot help but feel the fundamental thesis of this book is flawed. Pistor manages to write a book about modern capitalism with barely a mention of the role of the working class. This however flows logically from the premise that it is the legal code which creates wealth, rather than the exploitation of wage labourers by capitalists. The breezy narratives in her book are thoughtful and consistently well written. Yet it has the feel of an enthusiastic policy wonk who is explaining the world through an oversimplified and wrongheaded prism. Teaching at a law school which values social justice, I also cannot help but be skeptical about her self-congratulatory claims that the most creative lawyers are the small minority "trained at elite law schools" who work to design bespoke legal code for corporate deals as " $\mathrm{t}]$ he code's true masters." 35 Legions of highly creative criminal, family, and immigration lawyers would be taken aback at this claim. Overall, Pistor's intervention appears too simplistic and tries to cover far too much material in a short space.

\section{Democracy May Not Exist}

Saving the best for last we come to Taylor's Democracy May Not Exist. Written for a popular audience by a filmmaker known for her acclaimed documentaries including Zizek!, Examined Life and, most recently, What is Democracy?, this book is an intellectual tour de force. Taylor has written this book to explore the meaning of democracy or power by the people. While it only addresses legal issues in passing, they are present throughout. Taylor structures each chapter around two concepts, presumably in tension with each other: freedom and equality; coercion and choice; conflict and consensus; expertise and mass opinion; the local and the global; and the present and the future. Passionately written in a prose style that is reminiscent of Naomi Klein, Taylor reminds us of the too often forgotten democratic experiments of the ancient Greek city-states, in which decision-makers were selected by lottery. ${ }^{36}$ As Coccoma has recently demonstrated, citizen assemblies chosen by this method, known as 'sortition,' would have significant advantages. These advantages include greater legitimacy as democratic institutions accountable to the people, greater effectiveness through an increase in the diversity of decision-makers in a world where elected parliaments still struggle to represent women equally, and credibility that would break down divisions between the elites and the masses. ${ }^{37}$ Corporations would also find it difficult to use money to capture the votes of representatives selected by sortition. ${ }^{38}$

In stressing the advantages of sortition, Taylor encapsulates the overarching theme of the book: strengthening radical democracy. She consequently provides a counterpoint to the bureaucratic solutions proposed by Pistor, while supplementing the theoretical corpus articulated by Brabazon and her contributors. 
Taylor observes that "[s]election by lot may not be the perfect solution to the problems we face, but it suggests that other, radically different ways of structuring political participation and incorporating spontaneity are possible." 39 Even more impressively, Taylor makes apt allusions to Cornelius Castoriadis' notion of social imaginary significations, which refers to the central questions a civilization asks about itself, in order to understand the ancient Greek commitment to democracy. The co-founder of the legendary French radical group Socialisme ou barbarie, Castoriadis was always concerned with radical democracy and Taylor's inclusion of his work is entirely appropriate and well crafted.

This commitment to radical democracy allows her to make the important point that democracy and social movements go hand in hand. She appreciates that the very meaning of democracy is altered by the demands of social movements. Hence she notes insightfully that the radical disability rights movement in the United States, which highlighted the physical barriers prevalent in American society, paved the way for the passage of the Americans with Disabilities Act in 1990. ${ }^{40}$ Taylor's work dovetails nicely with the idea in Brabazon's collection that there is a co-constitutive relationship between neoliberalism and law. She also recuperates the lost history of ballot initiatives, referenda, and recall by petition, all ideas which can be traced to the Populist movement's demands in the 1890s and later for democratic reforms against the corruption of machine politics. ${ }^{41}$

One reason that Taylor is able to write such a consistently radical and insightful work is perhaps her unusual upbringing. As she explains in her text and in other writings, she and her siblings were homeschooled and raised in a non-coercive anti-authoritarian manner. ${ }^{42}$ It is therefore not surprising that she questions the role of hierarchy so consistently. A perceptive example is her critique of one-sided adhesion contracts including the use of compulsory arbitration clauses which parties must agree to for the settlement of disputes. While theoretically signifying agreement by two consenting parties, in fact such contracts mask enormous power differences. ${ }^{43}$ Similarly, women historically were deemed to be consenting to decisions made by their husbands who had complete control of their property.

A recurrent theme in radical critique is the presentation of the structural dilemmas of neoliberal capitalism without the presentation of solutions to these dilemmas. To her credit, Taylor takes the time to discuss some positive examples of how neoliberalism can be challenged. She describes one of the few cooperatively run factories in the United States, the New Era Windows Cooperative, on Chicago's South Side. This cooperative was established in the aftermath of the collapse of Republic Windows and Doors during the 2008 economic contraction. Taylor examines how under its new egalitarian structure workers are willing to exchange ideas that enhance productivity and take breaks as they wish. While workers were tightly regulated and polarized by racial tensions in the private sector regime, the freedom of a worker-owned cooperative allowed a flourishing of ideas that benefited the company. Similarly, a North Carolina cooperative, Opportunity Threads, is a textile 
factory that allowed workers to share profits equitably, contrasting dramatically with comparable private sector jobs where workers were denied sick days or even bathroom breaks. ${ }^{44}$

Each book ultimately provides different insights into the questions raised by neoliberalism. Whereas Taylor weaves a tale about the meaning of democracy, the impact of neoliberalism and law is ever-present. Taylor notes how advocates are increasingly litigating the impact of environmental damage from carbon dioxide emissions on future generations, a novel strategy that is likely to expand. ${ }^{45}$ Brabazon's anthology capably addresses the challenges of neoliberal legality in original and insightful ways. And, despite its flaws, Pistor's book offers a wealth of knowledge relating to legal instruments and their misuse by capitalists seeking to maximize profits. Together, these books offer the reader great insight into neoliberalism and how to challenge it. 


\section{NOTES}

${ }^{1}$ Katharina Pistor, The Code of Capital: How the Law Creates Wealth and Inequality (Princeton: Princeton University Press, 2019), 71-73.

${ }^{2}$ Pistor, The Code of Capital, 144-45.

${ }^{3}$ Pistor, The Code of Capital, 138-39.

${ }^{4}$ Kenneth Veitch, "Law, social policy and the neoliberal state" in Honor Brabazon, ed., Neoliberal Legality: Understanding the role of law in the neoliberal project (New York: Routledge, 2017), 82.

${ }^{5}$ Astra Taylor, Democracy May Not Exist, but We'll Miss It When It's Gone (New York: Metropolitan Books-Macmillan, 2019), 277.

${ }^{6}$ Honor Brabazon, "Introduction: Understanding neoliberal legality" in Brabazon, Neoliberal Legality, 1-2.

${ }^{7}$ Brabazon, "Introduction," 2-3.

${ }^{8}$ Brabazon, "Introduction," 3.

${ }^{9}$ Andrés Palacios Lleras, "Neoliberal law and regulation" in Brabazon, Neoliberal Legality, 62.

${ }^{10}$ Brabazon, "Introduction," 3.

${ }^{11}$ Brabazon, "Introduction," 3-4.

${ }^{12}$ Brabazon, "Introduction," 4.

${ }^{13}$ For a discussion of the impact of neoliberalism on disabled students, see Fady Shanouda and Natalie Spagnuolo, "Neoliberal methods of disqualification: a critical examination of disability-related education funding in Canada" Journal of Education Policy (2020) DOI: 10.1080/02680939.2020.1712741

${ }^{14}$ Brabazon, "Introduction," 5.

${ }^{15}$ Lleras, "Neoliberal law and regulation," 70-71.

${ }^{16}$ Nicolás M. Perrone, "Neoliberalism and economic sovereignty," in Brabazon, $N e$ oliberal Legality, 53-55.

${ }^{17}$ Perrone, "Neoliberalism and economic sovereignty," 51.

${ }^{18}$ Anglo-Iranian Oil Co. Case (United Kingdom v. Iran) [1952] ICJ 2.

${ }^{19}$ See Stephen Kinzer, All the Shah's Men: An American Coup and the Roots of Middle East Terror (Hoboken, New Jersey: John Wiley \& Sons, 2008).

${ }^{20}$ Robert Knox, "Law, neoliberalism and the constitution of political subjectivity," in Brabazon, Neoliberal Legality, 92; Ntina Tzouvala, "Continuity and rupture in restraining the right to strike," in Brabazon, Neoliberal Legality, 119. I focus only on the example of Knox.

${ }^{21}$ Knox, "Law, neoliberalism and the constitution of political subjectivity," 102-05.

${ }^{22}$ Knox, "Law, neoliberalism and the constitution of political subjectivity," 110.

${ }^{23}$ Vanja Hamzic, "Alegality: outside and beyond the legal logic of late capitalism," 
in Brabazon, Neoliberal Legality, 191.

${ }^{24}$ Hamzic, "Alegality: outside and beyond the legal logic of late capitalism," 198200.

${ }^{25}$ Pistor, The Code of Capital, 3.

${ }^{26}$ Pistor, The Code of Capital, 12-13.

${ }^{27}$ Pistor, The Code of Capital, 41.

${ }^{28}$ Pistor, The Code of Capital, 52-53.

${ }^{29}$ Pistor, The Code of Capital, 72.

${ }^{30}$ Pistor, The Code of Capital, 79-87.

${ }^{31}$ Pistor, The Code of Capital, 98-99.

${ }^{32}$ Pistor, The Code of Capital, 90.

${ }^{33}$ Pistor, The Code of Capital, 119-21.

${ }^{34}$ Pistor, The Code of Capital, 123-24.

${ }^{35}$ Pistor, The Code of Capital, 162.

36 Taylor, Democracy May Not Exist, 19-20.

${ }^{37}$ Nicholas Coccoma, “The Return of Democracy by Lottery” New Politics 17 no. 4 (2020), available online at https://newpol.org/issue_post/the-return-of-democracy-by-lottery/

38 Taylor, Democracy May Not Exist, 194.

39 Taylor, Democracy May Not Exist, 196.

40 Taylor, Democracy May Not Exist, 165.

41 Taylor, Democracy May Not Exist, 179.

42 Taylor, Democracy May Not Exist, 130. See also Astra Taylor, “The Unschooled Life: Astra Taylor's Story" (16 January 2014), available online at https://popularresistance.org/the-unschooled-life-astra-taylor-story/.

43 Taylor, Democracy May Not Exist, 138.

44 Taylor, Democracy May Not Exist, 156.

45 Taylor, Democracy May Not Exist, 277. 